\title{
SPECIFIC TRAINING ADJUSTMENTS FOR YOUNG DISCUS THROWERS AS A PREREQUISITE FOR ACHIEVING ELITE PERFORMANCE
}

\author{
Mensur Vrcić ${ }^{1}$, Ratko Pavlović ${ }^{2}$, Sid Solaković ${ }^{3}$, Erol Kovačević ${ }^{1}$ and Ensar Abazović $^{4}$ \\ ${ }^{1}$ Faculty of Sports and Physical Education, University of Sarajevo, Bosnia and Herzegovina \\ ${ }^{2}$ Faculty of Physical Education and Sports, University of East Sarajevo, Bosnia and Herzegovina \\ ${ }^{3}$ Clinic for Vascular Surgery, Clinical Center in Sarajevo, Bosnia and Herzegovina \\ ${ }^{4}$ Faculty of Kinesiology, University of Split, Croatia
}

Professional paper

\section{SUMMARY}

The aim of this paper is to demonstrate a model of specific discus thrower training adjustments, as well as depicting the most important characteristics of achieving elite performance. The most important aspects of the training programme have been taken into account, specifically those applied by discus throwers who have achieved significant improvements in their season. The improvement is indicated in the result of 58, $34 \mathrm{~m}$ (within the year 2016) compared with the result of 47,72m achieved in 2015, with the disc weight of $1,5 \mathrm{~kg}$ in the category $U 18$, representing a significant difference of 10,62 $\mathrm{m}$. The result was achieved at the European Athletic Championship in the youth category. The attained result is likewise a personal best, and has been achieved during the finals of European Championship as perceived.

Key words: discus throw, elite performance, training programme

\section{INTRODUCTION}

The speed of result improvement in athletic throwing events is preconditioned by the application of scientific research. Achieving superior sport performance is a direct result of athlete's adjustment to the various types and methods of training (Bompa, 2001). During the competition, to be exact during the most important competition, an athlete is to achieve top results which requires a sequence of cumulative activities to be performed so as to deliver maximum sport performance at the most important annual competition. During this last 
development phase, a child goes through a transition from youth to an adulthood (Andrijašević 2010). The discus throw is an athletic event, by which contestants go through a long competition period. Al Oerter, an American disc thrower, is an example of an athlete who has succeeded in attaining a long and prosperous career, with a result of $69,46 \mathrm{~m}$ achieved when he was 43 years of age. If a disc thrower is to maintain a high level of performance during his lifetime, it is necessary to design a qualitative and thorough preparation. Disc throwers who achieve good results as junior contestants but later are unable to achieve not as nearly expected results, are not a rare case. In that sense, it is not unlikely that we have "skipped some steps" in the long-run planning and programming, nor the fact that the training started earlier than is intended for the adult athletes - seniors (early specialisation). Maintaining a high level of physical fitness enables a development of better expertise in later stages. Of course, one needs to take into account the modern tendency for reducing the age of sport readiness. The subject whose parameters are applied in this paper are those of a disc thrower who has during his first year (out of two) won a fourth place at the European Athletic Championship in the U 18 category in Tbilisi (GEO), achieving a result of $58,34 \mathrm{~m}$, and who is likewise a member of the national team of Bosnia and Herzegovina in the event of discus throw and shot put in the pioneers and youth category.

\section{DISCUSSION}

In the previous year the best result of $47,72 \mathrm{~m}$ in the event of $1,5 \mathrm{~kg}$ discus throw was achieved during the Balkan Alethic Championship for the youth category. The best result of 58,34m for the season (2016) was as well a personal best. During the semi-finals the achieved result and a personal best was $57,14 \mathrm{~m}$ (up to that moment the personal best 56,04m was attained at Croatian Open Throwing Championship in Split). The overall seasonal improvement of $10,62 \mathrm{~m}$ is an assumption for a successful performance (medal - winning) for the following year at the World Championship in Kenya. An important attribute of athlete performance is the ability to tolerate different levels of frustration which emerge prior, during and after the competition (Bowerman, Freeman \& Gambeta, 2012). Top performance has been planned for the European Championship in Tbilisi (Georgia), where it was ultimately achieved, as well as for the following season competition, which is World Championship in Nairobi (Kenya). Taking into consideration that the subjects in this season are one year older contestants (the three top rated), and also 
considering their peers and upcoming results, expectations are realistic that a medal will be won at the World Championship.

Considering that an athlete has entered into a specialization phase and can handle greater training and competition demands, exercises which aim at elite performance development have been carefully introduced (Bompa, 2001). During training planning, which is a main task of every coach, special attention has been placed to a disc throwing technique and primary movement exercises which athletes use during their technical performances. Diet is based on taking natural base products and attaining nutrition from healthy sources.

Based on the analysis of the motor ability tests, taken in 2015, prior to the beginning of the season, as well as the analysis of previous trainings, it has been concluded that disc thrower during his current development period has exhibited lower level of some general and specific motor abilities.

Table 1 Motor test results for 2015 and 2016, as well as the plan for 2017

\begin{tabular}{|c|c|c|c|c|c|}
\hline Test & 2015 & 2016 & $\begin{array}{c}\text { difference } \\
\mathbf{2 0 1 6 / 1 7}\end{array}$ & Plan for 2017 & $\begin{array}{c}\text { Elite senior disc } \\
\text { throwers } \\
\text { (modal characteristics) }\end{array}$ \\
\hline Power snatch (strength) & $65 \mathrm{~kg}$ & $80 \mathrm{~kg}$ & $15 \mathrm{~kg}$ & $95 \mathrm{~kg}$ & $135-140 \mathrm{~kg}$ \\
\hline Deep Squat & $135 \mathrm{~kg}$ & $160 \mathrm{~kg}$ & $25 \mathrm{~kg}$ & $180 \mathrm{~kg}$ & $270-280 \mathrm{~kg}$ \\
\hline Bench Press & $110 \mathrm{~kg}$ & $120 \mathrm{~kg}$ & $10 \mathrm{~kg}$ & $140 \mathrm{~kg}$ & $240-260 \mathrm{~kg}$ \\
\hline Double-leg triple jump & $635 \mathrm{~cm}$ & $705 \mathrm{~cm}$ & $70 \mathrm{~cm}$ & $810 \mathrm{~cm}$ & $10,00-10,50$ \\
\hline 30m sprint - flying start & $4,58 \mathrm{~s}$ & $4,33 \mathrm{~s}$ & $-0,25 s$ & $4,10 \mathrm{~s}$ & \\
\hline $\begin{array}{l}3 \mathrm{~kg} \text { static shot put, like discus } \\
\text { throw }\end{array}$ & $21,45 \mathrm{~m}$ & $26,60 \mathrm{~m}$ & $5,15 \mathrm{~m}$ & $32,50 \mathrm{~m}$ & $45 \mathrm{~m}$ \\
\hline $5 \mathrm{~kg}$ shot put, over the head & 13,67 & $17,10 \mathrm{~m}$ & $3,43 \mathrm{~m}$ & $21,00 \mathrm{~m}$ & $21-22 \mathrm{~m}(7,26 \mathrm{~kg})$ \\
\hline $1,5 \mathrm{~kg}$ static discus throw & $37,20 \mathrm{~m}$ & $46,55 \mathrm{~m}$ & $9,35 \mathrm{~m}$ & $53,50 \mathrm{~m}$ & \\
\hline $2 \mathrm{~kg}$ discus throw from rotation & $40,03 \mathrm{~m}$ & $48,28 \mathrm{~m}$ & $8,25 \mathrm{~m}$ & $54,00 \mathrm{~m}$ & $68-72 \mathrm{~m}$ \\
\hline $\begin{array}{c}1,5 \mathrm{~kg} \text { discus throw from } \\
\text { rotation }\end{array}$ & $47,72 \mathrm{~m}$ & $58,34 \mathrm{~m}$ & $10,62 \mathrm{~m}$ & $65,00 \mathrm{~m}$ & \\
\hline
\end{tabular}


Diagram 1. Test results for general strength assessment in 2015 and 2017, as well as the plan for 2017

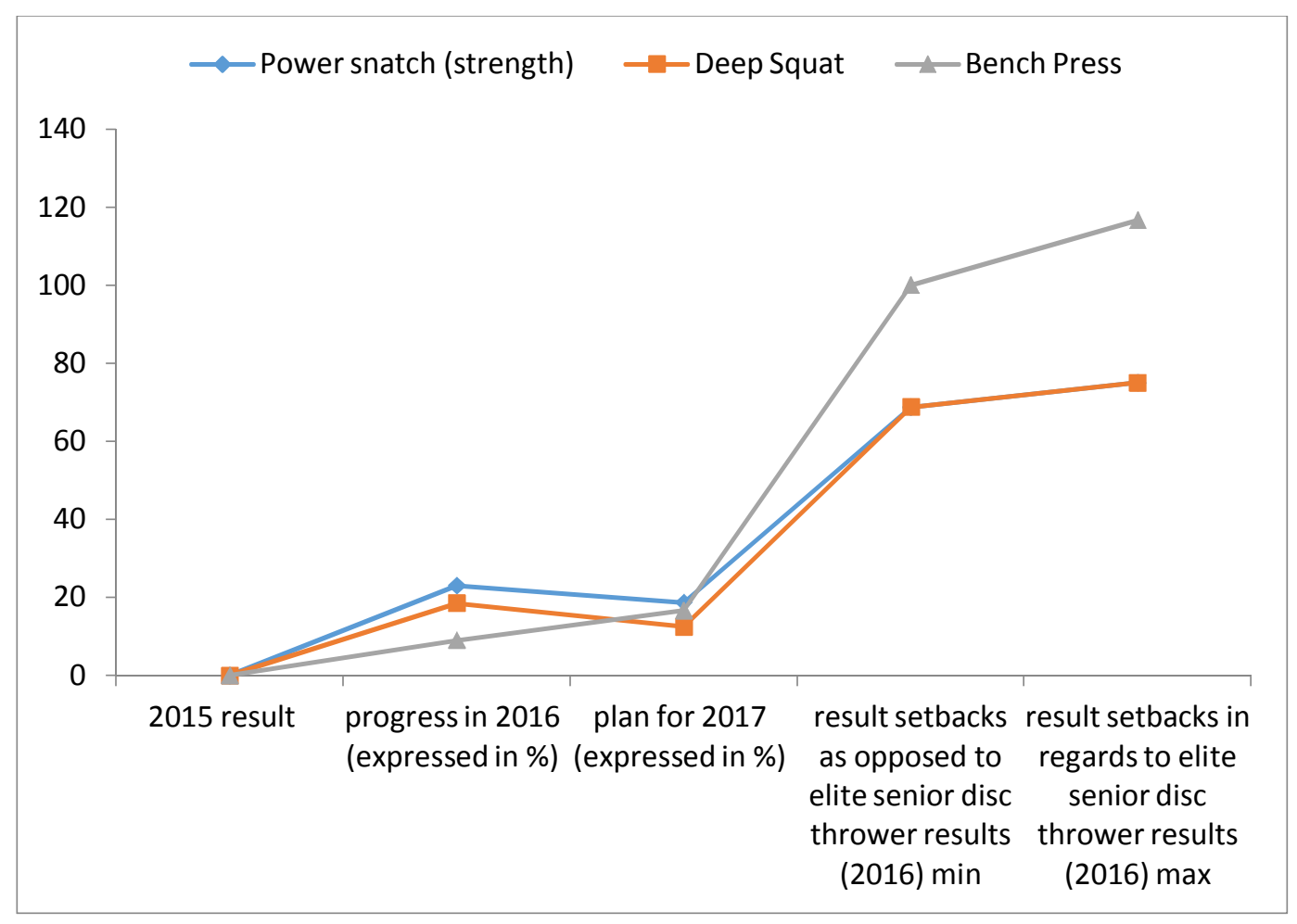

Diagram 2. Test results for explosive strength assessments in 2015 and 2016, as well as the plan for 2017

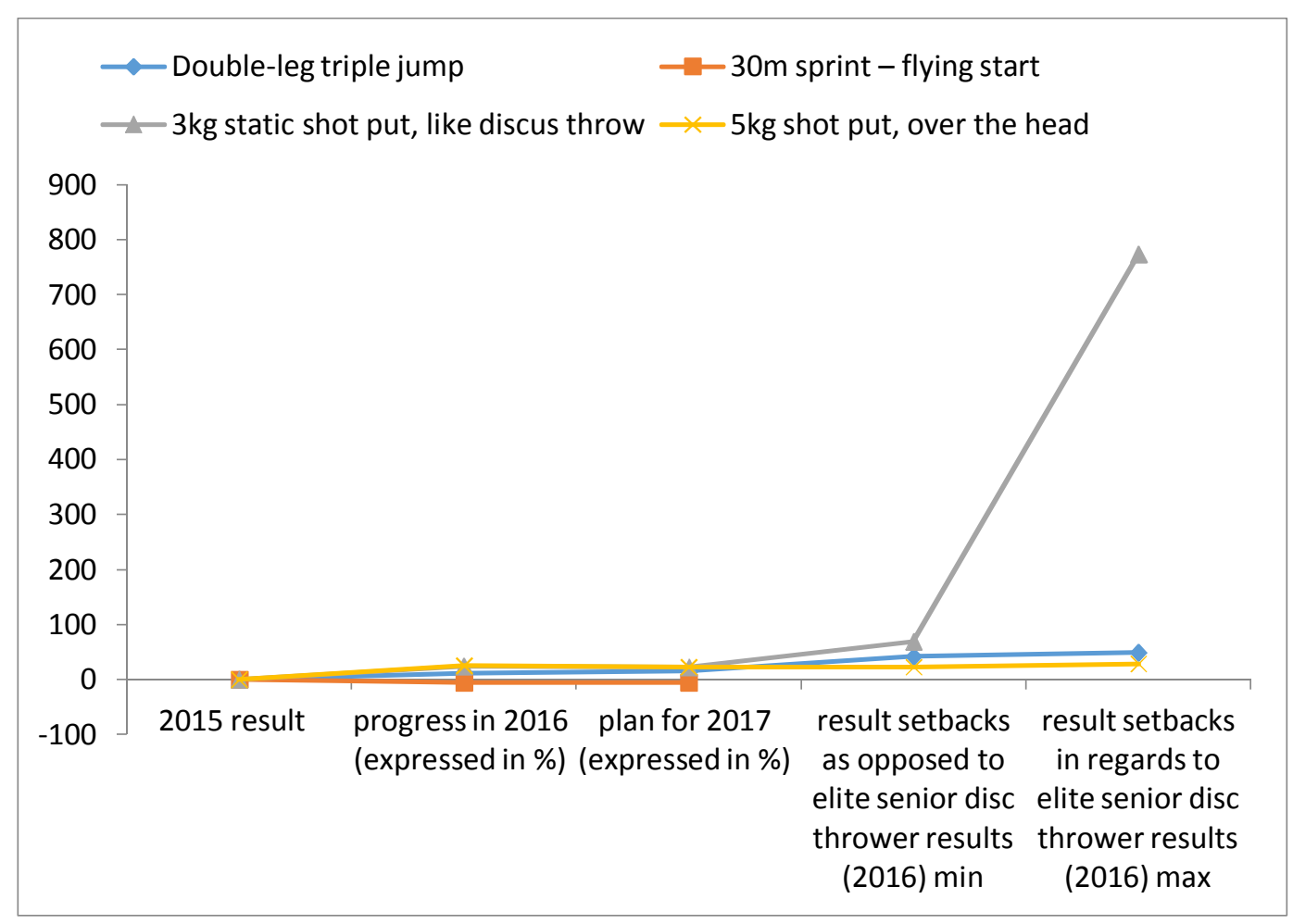


Diagram 3. Results achieved for the discus throw event (indicator of sport performance) in 2015 and 2016, as well as the plan for 2017

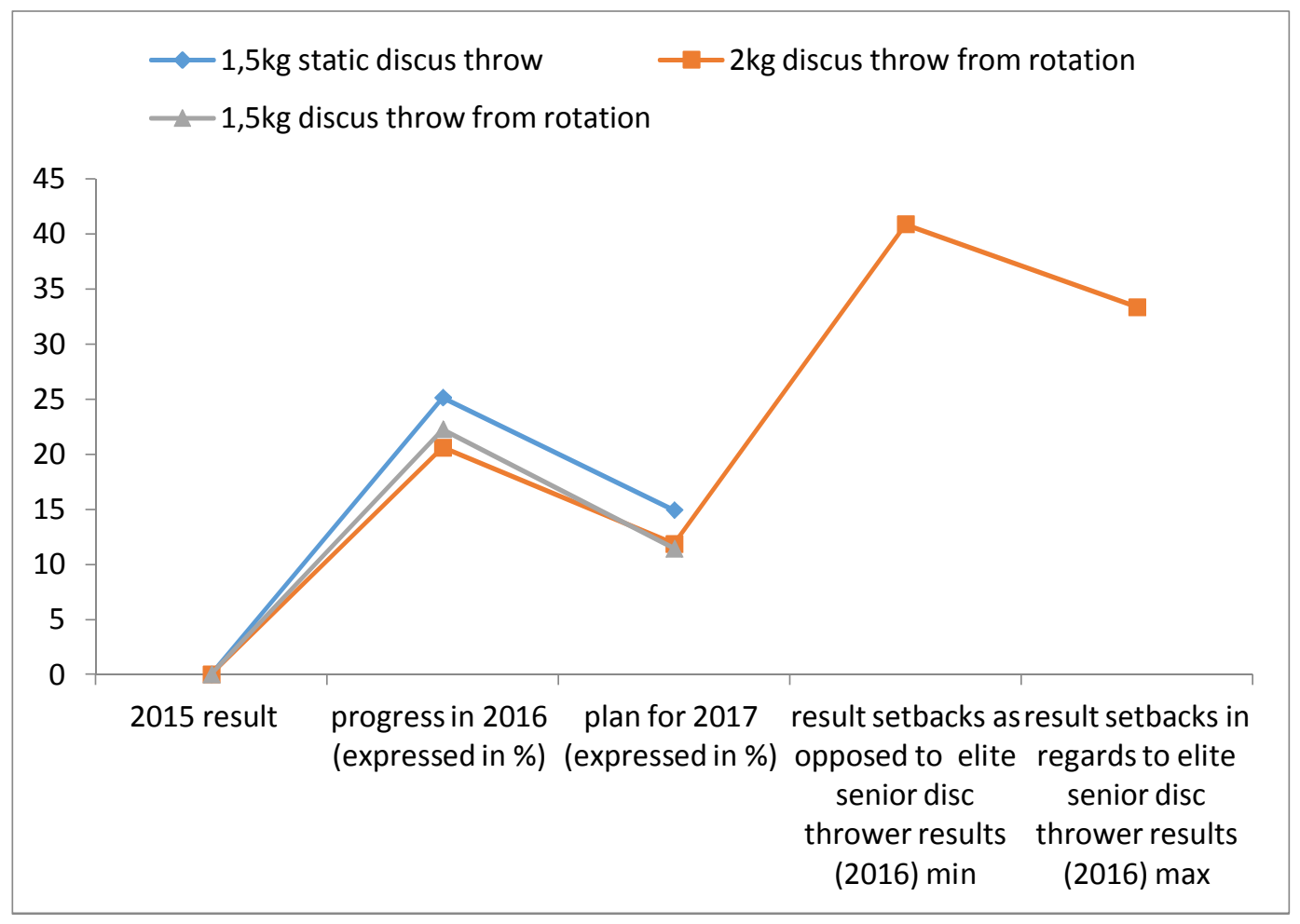

The deficits exhibited in the motor ability tests (static triple jump, sprint 30m) often limit the technical performance. During this period, athletes should have a high level of technical performance, which should be insisted upon if one is to use motor abilities to its maximum. A good indicator of a high level technique is the difference between static throwing and throwing from rotation. The greater the difference, the thrower can exhibit greater velocity during release. The disk thrower category U18 is able to throw $1,5 \mathrm{~kg}$ disc. In trainings, apart from using the prescribed weight of $1,5 \mathrm{~kg}$, one can use lighter $(1 \mathrm{~kg}, 1,25 \mathrm{~kg})$, or heavier training tools $(1,75 \mathrm{~kg}$, $2 \mathrm{~kg}$ ). Coach's creativity and skill is reflected in composing the appropriate throwing distribution for different training tools throughout the entire year, as well as planning the numbers and lengths.

During the competition period the following activities have taken place:

- the number of overall throws was reduced (different throwing techniques, such as shot put in front, over, into the air, etc. ), but the number of shots in half-rotation and full rotation was increased; 
- Throwing intensity was gradually increased for the last 10 days right before the start of the competition when the intensity was lowered from $90-95 \%$ to $70-80 \%$;

- Training sessions with the application of weights have for the last month been assigned to specific disc thrower exercises (extended arms stretching on the bench, body twist with shoulder weights, plate side bends). The most applied exercises were those of explosive character (snatch, clean, half squat jumps, bend jumps), initiated from the knees or from the middle of thighs with a minimum requirement of keeping the weights steady after the lift;

- for the last month $2 \mathrm{~kg}$ disc throw was excluded, while the smaller weight was included instead $(1,25 \mathrm{~kg}) 2$ times per week, and $1,75 \mathrm{~kg}$ once a week. Competition weight was applied twice a week.

- the number of exercises for stretching specific musculoskeletal segments which partake in throwing activities were increased;

U18 Category is a youth category for contestants of 16 and 17 years of age.

Even though the training itself is taking on the characteristics of a senior contestants' training, one must honour the specificities of a young body so as not to lead to stagnant results. During the specialisation phase, as a phase of sport development, the focus has been placed on selected sport training. Foundations laid out during the specialization phase will enable a better performance for the elite phase (Bompa, 2001).

\section{CONCLUSION}

Based on the analysis of results achieved in 2015 and 2016, one can state that significant improvement in disc throwing results have been achieved. The results attained were during the most important competitions in a season, which is due to optimum dosage of intensity and volume during the season, as well as specific adaptations made for the planned sport performance. There is still enough place for further improvement in results, because not all condition training capacities have been applied. Great number of parameters do not satisfy the modal characteristics laid down in some tests, which should represent one of the tasks for the improvement of bad performance. Prerequisite for further throwing improvement is constant technique development and increasing general and specific abilities. By the end of "sport 
education", many athletes who have developed solid foundations and wish to achieve top results in a specific sport, will be able to specialize in it. (Bompa, 2005).

\section{REFERENCES}

Andrijašević, M. (2010). Kineziološka rekracija. Zagreb, RH: Kineziološki fakultet Sveučilišta u Zagrebu.

Bowerman, W. J., Freeman, W., H., \& Gambetta., V. (2012). Atletika - periodizacija, tehnika i program treninga za sve discipline. Zagreb, RH: Gopal.

Bompa, T. (2005). Cjelokupan trening za mlade pobjednike. Zagreb RH: Gopal.

Bompa, T. (2001). Periodizacija: teorija $i$ metodologija treninga. Zagreb RH: Hrvatski košarkaški savez.

Received: 11.05.2017.

Accepted: 20.06.2017.

Correspondence author:

Mensur Vrcić, PhD

Faculty of Sports and Physical Education

University of Sarajevo

Patriotske lige 41,

Sarajevo 71000 ,

Bosnia and Herzegovina

Tel: +38733668768

Fax: +38733211537

mvrcic@,fasto.unsa.ba 